\title{
INVESTIGATING THE IMPACT \\ OF SALESPERSONS' USE OF \\ TECHNOLOGY AND SOCIAL MEDIA \\ ON THEIR CUSTOMER RELATIONSHIP \\ PERFORMANCE IN B2B SETTINGS
}

\section{ISTRAŽIVANJE UTJECAJA PRODAVAČEVA KORIŠTENJA TEHNOLOGIJE I DRUŠTVENIH MEDIJA NA UČINKOVITOST ODNOSA S POTROŠAČIMA NA POSLOVNOM TRŽIŠTU}

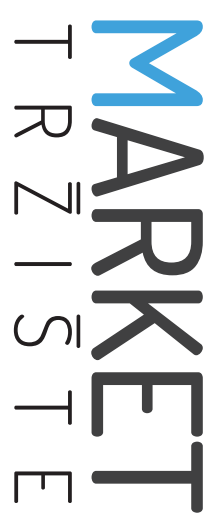

Market-Tržište

Vol. 30, №. 2, 2018, pp. 165-176

UDK 004.73:316.77:658.89

DOl http://dx.doi.org/10.22598/mt/2018.30.2.165

Preliminary communication

Mirkó Gátia , Ariel Mitev ${ }^{b}$, András Bauerc

a) Corvinus University of Budapest, Fóvám tér 8., H-1093, Budapest, HUNGARY, e-mail: mirko.gati@uni-corvinus.hu

b) Corvinus University of Budapest, Fővám tér 8., H-1093, Budapest, HUNGARY, e-mail: ariel.mitev@uni-corvinus.hu

c) Corvinus University of Budapest, Fővám tér 8., H-1093, Budapest, HUNGARY, e-mail: andras.bauer@uni-corvinus.hu

\begin{abstract}
Purpose - Salespeople have had a long affair with technology in serving customers. Some research studies, however, indicate that too much technology may have a negative impact on salespeople's social skills. This paper aims to analyze what impact technology - specifically, social media, in terms of attitudes and use - has on selling performance.
\end{abstract}

Design/Methodology/Approach - In a sample of salespeople from different business-to-business (B2B) industries, respondents were surveyed in the form of face-to-face interviews that were conducted at their place of work. The study analyzed how the intensity of technology use, attitudes towards and the use of social media affect customer relationship performance. Variance-based structural equation modeling, especially PLS-SEM, was applied for the analysis.

\section{Sažetak}

Svrha - U usluživanju potrošača prodavači su već dugo povezani s tehnologijom. Međutim neka istraživanja pokazuju da bi previše tehnologije moglo negativno utjecati na društvene vještine prodavača. Cilj rada jest analizirati utjecaj tehnologije, konkretno društvenih medija - stava i uporabe na učinkovitost prodaje.

Metodološki pristup - U uzorku prodavača iz različitih industrija poslovne potrošnje ispitanici su bili osobno ispitani anketiranjem na radnome mjestu, uz pomoć anketara. Analizirano je kako intenzitet korištenja tehnologije, stav o društvenim medijima i uporaba društvenih medija utječu na učinkovitost odnosa s potrošačima. Za analizu je korištena metoda modeliranja strukturnih jednadžbi na bazi varijance, osobito parcijalnih najmanjih kvadrata (PLS-SEM).

Rezultati i implikacije - Temeljem rezultata provjereni su učinci intenzivnog korištenja tehnologije na stav o društvenim medijima i uporabu društvenih medija te na 
Findings and implications - According to the results of this study, the effects of intensive technology use on social media attitude and use, as well as on customer relationship performance, are verified. The objective of this research, namely, to understand the influence of technology use and social media attitude and use on selling performance, has been partly achieved: the presumed positive theoretical connection between social media and performance is not trivial, although company managers should be aware the risks involved with the application of technology in sales.

Limitations - These results highlight that, if the focus is solely on social media, the effects of social media attitude and social media use on customer relationship performance are limited, and their explanatory power is relatively low. Therefore, a business model that focuses solely on customer retention mostly through the increased use of social media seems to have serious limitations. This study suffers from further limitations, such as small sample size and the exploratory nature of the research. Moreover, the findings are derived from perceived constructs and not from actual behavior.

Originality - The analysis of technology and social media is new in the current context. With the large scale of social media use being a relatively new phenomenon, this study can presumably provide a new understanding of social media in the selling environment.

Keywords - customer relationship performance, personal selling, social media, technology use uspješnost odnosa s potrošačima. Cilj istraživanja, razumijevanje uporabe tehnologije i stavova o društvenim medijima te njihova korištenja na učinkovitost prodaje, djelomično je ostvaren. Pretpostavljena pozitivna teorijska povezanost između društvenih medija i učinkovitosti nije beznačajna, a menadžeri poduzeća trebali bi biti svjesni činjenice da primjena tehnologije u prodaji može biti rizična.

Ograničenja - Rezultati ističu da ako je fokus isključivo na društvenim medijima, utjecaji stavova o društvenim medijima i korištenja društvenih medija na učinkovitost odnosa s potrošačima su ograničeni; njihov objašnjavajući potencijal je relativno nizak. Čini se da zbog toga poslovna praksa koja se isključivo usmjerava na zadržavanje potrošača uglavnom kroz povećanu uporabu društvenih medija, ima ozbiljnih ograničenja. Istraživanje ima i dodatnih ograničenja kao što su mala veličina uzorka ili izviđajna narav istraživanja. Osim toga, rezultati potječu od percipiranih konstrukata, a ne od stvarnog ponašanja.

Doprinos - Analiza tehnologije i društvenih medija nova je u aktualnom kontekstu. Ljestvica za mjerenje uporabe društvenih medija u svojem je sadašnjem obliku relativno nova tako da vjerojatno može pružiti novo razumijevanje društvenih medija u prodajnom okruženju.

Ključne riječi - učinkovitost odnosa s potrošačima, osobna prodaja, društveni mediji, korištenje tehnologije 


\section{INTRODUCTION}

Internal and external factors affect companies' sales activities, and one of these factors is the technological environment in which these firms operate (Jones, Brown, Zoltners \& Weitz, 2005). Technology is becoming more and more significant in sales, as technology acceptance-, and application-oriented literature sources refer to (e.g. Schillewaert, Ahearne, Frambach \& Moenaert, 2005), and as demonstrated by the inclusion of social media into previously existing CRM systems (Trainor, Andzulis, Rapp \& Agnihotri, 2014) that can support both the selling process and competitive intelligence gathering (Itani, Agnihotri \& Dingus, 2017). How intensely technology is used depends on factors such as the everyday micro-environment in which salespeople live (co-workers, management), as well as the broader, external environment (e.g. the technology use of competitors). According to Weinstein and Mullins (2012), an important influencing factor of technology acceptance is how salespeople in the company perceive the use of technology of their competitors.

There was an observable paradigm shift in sales that moved from transaction-oriented marketing towards relationship marketing (Weinstein \& Mullins, 2012). Companies utilize resources to reach a sustainable competitive advantage by building close, cooperative relationships with their buyers (Weitz \& Bradford, 1999). These companies had to change from an exclusively sales-oriented perspective towards providing increasingly effective service. The elements of this tendency are different customer relationship management (CRM) systems and sales force automation (SFA) tools ${ }^{1}$ and their development and spread. With these tools, salespeople can analyze their customer data more efficiently and effectively, even from a long-term perspective (Moutot \& Bascoul, 2008). Technology enables salespeople to acquire, store, and analyze customer data, and to create customer-based business solutions from these data (Jones et al., 2005: 109). With the help of technology, real-time communication gradually develops, mostly with customers. Thus, technology applied in sales mainly improves communication, since multiple online and mobile platforms, including diverse social media outlets, have made it possible for salespeople to communicate more effectively with their buyers, improve sales practices, and develop interorganizational relationships.

Social media in sales is a technological component of a company's communications, business transactions, and relationship building that affects the customer network and enables the creation of shared values (Andzulis, Panagopoulos \& Rapp, 2012: 308). Companies vary in terms of their communication preferences on different social media platforms (e.g. Facebook, Linkedln, Twitter, YouTube). Sales organizations can choose among social networks, forums, blogs, content communities, or collaborative projects to accomplish their communicational, transactional, and relational dimensions. A recent study by Forrester (2017) claims that there is a wide variety of tasks for which sales organizations can use social media, ranging from listening to after-sales services. There are many great examples, such as the IBM Smart Cloud for enterprises, which supports the integration of different social media platforms and supports the selling process.

The role of social media has grown not only generally, but specifically in the sales profession. It can be concluded that personal sellers can benefit from social media solutions, mainly in an interorganizational context (Guesalaga, 2016); companies in these markets are still in the initial phase of understanding the potential of social media in selling, and their use is in the introductory phase.

Nevertheless, while the role of certain platforms (e.g. Linkedln, Facebook, Twitter) in social sales can be more significant, the overall role of social media has increased in the past few years (e.g. forecast, lead ${ }^{2}$ qualification, customer relationship management), so it can affect the whole selling process: the understanding of the customer (e.g. participation in specific Linke- 
dln groups); reaching customers (e.g. content creation and sharing on Facebook or on Twitter); the exploration of customer needs (e.g. the creation of a blog); value provision (e.g. YouTube videos); closure of the purchase (e.g. orientation of the customer from Facebook to the sales channel); post-purchase services (e.g. following customers on Twitter) (Guesalaga, 2016). Moreover, social media can affect the creation and maintenance of the personal relationship between the buyer and the seller.

\section{TECHNOLOGY AND SOCIAL MEDIA USE IN THE SELLING PROCESS}

Modern selling involves multiple technologies such as social media tools, and this can affect the buyer-seller relationship, the role of the salesperson, and the sales organization (Marshall, Moncrief, Rudd \& Lee, 2012). The intensity of technology use in sales is the rate of at which selling organizations apply information technology (e.g. CRM, SFA, or any customer-focused sales technology that is built on information technology), mainly to build more efficient and effective ways of dealing with their customers (Gatignon \& Robertson, 1989; Schillewaert et al., 2005). For instance, as selling companies integrate social media elements into their CRM systems (Trainor, 2012), already-existing technological systems enable these social media elements to be built in, giving salespeople a positive attitude about their ability to implement these new systems. According to Guesalaga (2016), greater technology use has a positive effect on sales performance in multiple ways, including better and more accurate intelligence gathering or the possibility of quicker reactions. Attitude towards social media in this sense is highly connected with salespeople's better communications with existing business partners, their ability to communicate and build relationships with new partners, and having a tool that facilitates the entire sales process (Durukan \& Bozaci, 2012). Thus, it can be presumed that companies with inten- sive technology use consider social media to be such a technological platform that can maintain or improve inter-organizational relationships. Salespeople can develop a mindset that, relying on social media, can enrich their understanding of client needs while also allowing them to tailor messages to clients according to their preferences. Social media use from the aspect of the selling process is mainly focused on getting information from buyers and contacting current or potential business partners (Rodriguez, Peterson \& Krishnan 2012; Demand Gen Report, 2014). Using social media not only has the potential to improve the understanding of what clients prefer, but can also enhance a feeling of community, e.g. by reading and posting content on Linkedln Groups. Overall, a positive correlation is predicted between technology use and the use of social media.

Hypothesis 1: More intensive technology use leads to a more positive attitude towards social media.

Hypothesis 2: More intensive technology use leads to more social media use.

More intensive investments in technology result in higher expectations from the output side of the process. If technology is applied properly by companies, then performance can improve, because salespeople can efficiently use technology that may lead to higher performance (Avlonitis \& Panagopoulos, 2005; Rapp, Ahearne, Mathieu \& Rapp, 2010).

Technology use can be indirectly connected to performance (Guesalaga, 2016), but it may have certain limitations from an organizational perspective: the application of certain CRM/SFA systems does not work without the right level of planning, without sufficient communication in the organization; it is not always evaluated fairly and is not always harmonized with salespeople's aims (Honeycutt, Thelen, Thelen \& Hodge, 2005; Christ \& Anderson, 2011). Ahearne, Jones, Rapp and Mathieu (2008) found a strong positive correlation between technology use (mostly SFA) and sales performance. The use of technology is primarily driven by better in- 
formation about buyers and by better service. In this paper, sales performance is built on the presumption that performance is based on a company's resources and its effectiveness in turning those resources into capabilities (Trainor et al., 2014: 1202). In terms of sales activities, and with the assumption that technology has made it possible for organizations to both have better interactions with customers and use customer information more effectively and efficiently, the performance of customer relationships is a relevant measure for sales organizations (Trainor et al., 2014). Customer relationship performance is the extent to which firms are successful at satisfying and retaining loyal customers, compared to their competitors (Rust, Moorman \& Dickson, 2002; Rapp, Trainor \& Agnihotri, 2010). Since the sales force is provided with more tools to use and tailor them to clients' specific needs, it is predicted that this can have a positive impact on buyer-seller relationships.

Hypothesis 3: More intensive technology use leads to better customer relationship performance.

In the past, several analyses were conducted to reveal the antecedents of social media use in sales. These studies assumed that organizational attitude and motivation towards social media - mainly in the case of salespeople - correlates with social media use (Levin, Hansen \& Laverie, 2012). The antecedents of social media use were analyzed by Schultz, Schwepker and Good (2012), who used several factors measured on salespeople. Their study analyzed the effects of several attitude-based factors that can affect the social media use of the organization. Agnihotri, Kothandaraman, Kashyap and Singh (2012) analyzed the effect of social media use on value creation. The aforementioned studies revealed a positive relationship between attitude towards social media and social media use.

Hypothesis 4: A more positive attitude towards social media leads to more social media use.

Marshall and others (2012) also mention that technological tools enabling the development and maintenance of customer relationships, if applied in sales, indirectly affect the quality of customer relations because those social media tools affect buyer-seller interaction. This new kind of connection - besides decreasing the significance of personal interaction, and in so doing, risking the quality of the relationship - decreases information asymmetry between the buyer and seller, making the sales process more efficient and personalized (Guesalaga, 2016).

The relationship between social media use and performance appears in the studies of Rodriguez and others (2012) and Schultz and others (2012). Based on their results, the intensity of social media use and performance are positively correlated in the following manner: the ability to predict opportunity creation and the improvement of business connections both affect customer relationships favorably. Social media use, which plays an important role in communication with buyers and in the development of buyer experience, therefore indirectly affects customer relationship performance (Guesalaga, 2016). By the integration of social media and traditional CRM systems, sales organizations are better able to improve their performance. Multiplayer relationships, interactive dialogs, and information sharing among buyers and the sales organization enable common value creation with buyers, and thus, the company can be ready to develop its buyer-related relationship performance.

Hypothesis 5: A more positive attitude towards social media leads to better customer relationship performance.

Hypothesis 6: More social media use leads to better customer relationship performance.

The interrelations of the hypotheses constitute the theoretical framework of the present study (Figure 1). The analysis of technology and social media was not present in the former studies in the actual context (CRM and SFA were naturally analyzed in many ways). The scale of social media use is new in its present form, so it presumably can give new understanding to social media in this specific context. 
FIGURE 1: The effect of the intensity of technology use and social media use on customer relationship performance in personal selling

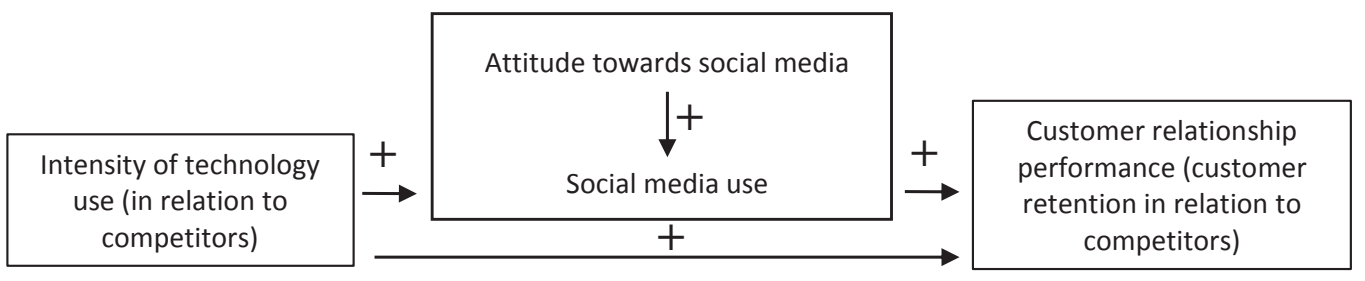

Source: authors' own elaboration

\section{DATA COLLECTION AND SAMPLING}

The aim of the sampling was to find salespeople from several industries who were willing to voluntarily fill out a questionnaire survey after an interview. Non-probability sampling, especially a convenience sampling technique, where the selection of sampling units was left primarily up to the interviewers, was applied. Data collection was made in spring 2016, and altogether, 112 responses were available for analysis after data clearing. The data was collected in the form of face-to-face workplace surveys with the help of interviewers, whose task it was to first contact the participants, then interview them and record their responses. All participants were interviewed in their workplaces, so they would have the comfort and security of their office. The respondents predominantly sell to B2B clients in the finance and insurance (34\%), commercial services (35\%), IT services (13\%), and real estate (12\%) industries. The respondents all use different CRM systems. They use social media (predominantly Facebook) with varying intensity, but mainly for generating information about clients. Some $70 \%$ of the respondents were men and $30 \%$ were women, their median age was 36 years, and the median time spent in sales 10 years. Sample units were all salespeople; this is a limitation - single source bias - that gives only the opinions and perceptions of one group of respondents.

To test the model, a type of variance-based structural equation modeling was applied, namely
PLS-SEM. Data analysis was conducted with ADANCO software (Dijkstra \& Henseler, 2015). The exploratory nature of this research study and its small sample size justified the use of PLS-SEM (see, e.g. Hair, Sarstedt, Ringle \& Mena, 2012).

\section{MEASURES AND QUALITY CRITERIA OF THE MEASUREMENT MODEL}

In the present study, such scales that had primarily been pre-tested in international studies or adapted to the peculiarities of personal selling were applied (see Appendix). Customer relationship performance was measured by the five-item scale of Trainor and others (2014) that measures customer retention in relation to competitors. To measure attitude towards social media, the four-item scale of Durukan and Bozaci (2012) was applied to personal selling, which is why the term "friends" was replaced by "partners" in the statement. Social media use is a scale developed for this research, which was based on an international B2B study's results (Demand Gen Report, 2014). Intensive technology use was based on the four-item scale of Gatignon and Robertson (1989) in a way that salespeople determined their technology use related to their competitors. Every statement was measured on a seven-point Likert scale. The numerous adapted or modified scales involved the use of PLS-SEM.

On the one hand, convergent validity can be tested with standardized factor loadings that 
should be more than .5 (.4 in case of exploratory research), but it is better to reach .7 (Hair et al., 2012). The appendix indicates Dijkstra-Henseler's $\rho_{\mathrm{A}}$ values, the index of internal consistency reliability measure of constructs, which is high above the favorable 7 value in every case (Dijkstra \& Henseler, 2015).

To clearly discriminate between two factors, HTMT should be significantly smaller than 1 (Henseler, Hubona \& Ray, 2016). Data meet the required criteria of discriminant validity (see Table 1).

Common method bias was examined using Harman's single factor test. Concerning the test, no single factor accounts for most of the variance in the model (only $33.5 \%$ is explained by a single factor), according to Podsakoff and Organ (1986).
In sum, sufficient statistical evidence was found to verify the existence of the four constructs and to verify that the measured variables are appropriate indicators of the related factors.

\section{STRUCTURAL MODEL AND RESULTS}

Only one model fit criterion is applied in PLS modeling, namely, the Standardized Root Mean Square Residual (SRMR), which has a cut-off value of .08 (Hu \& Bentler, 1999). The model delineated in this study has an appropriate model fit, because $S R M R=.072$. Based on the results (Table 2 and Figure 2), it can be seen that not every hypothesis was accepted.

TABLE 1: Discriminant validity HTMT

\begin{tabular}{|l|c|c|c|c|}
\hline Construct & $\begin{array}{c}\text { Intensive } \\
\text { technology } \\
\text { use }\end{array}$ & $\begin{array}{c}\text { Social } \\
\text { media } \\
\text { attitude }\end{array}$ & $\begin{array}{c}\text { Social media } \\
\text { use }\end{array}$ & $\begin{array}{c}\text { Customer } \\
\text { relationship } \\
\text { performance }\end{array}$ \\
\hline Intensive technology use & .5291 & & & \\
\hline Social media attitude & .3989 & .4853 & & \\
\hline Social media use & .3404 & .00284 & .0132 & \\
\hline $\begin{array}{l}\text { Customer relationship } \\
\text { performance }\end{array}$ & & & \\
\hline
\end{tabular}

Source: authors' own elaboration

TABLE 2: Direct effects in the model

\begin{tabular}{|c|c|c|c|}
\hline Direct effects & $\begin{array}{l}\text { Path } \\
\text { coefficients }\end{array}$ & t-value & p-value \\
\hline $\begin{array}{l}\text { Intensive technology use } \rightarrow \text { Social media attitude } \\
(\text { Hypothesis } 1+)\end{array}$ & .4862 & 6.2581 & .0000 \\
\hline Intensive technology use $\rightarrow$ Social media use (Hypothesis $2+$ ) & .1903 & 2.2694 & .0235 \\
\hline $\begin{array}{l}\text { Intensive technology use } \rightarrow \text { Customer relationship } \\
\text { performance (Hypothesis } 3+\text { ) }\end{array}$ & .3974 & 5.0301 & .0000 \\
\hline Social media attitude $\rightarrow$ Social media use (Hypothesis $4+$ ) & .3603 & 4.3009 & .0000 \\
\hline $\begin{array}{l}\text { Social media attitude } \rightarrow \text { Customer relationship performance } \\
(\text { Hypothesis } 5+\text { ) }\end{array}$ & -.1250 & -1.3864 & .1659 \\
\hline $\begin{array}{l}\text { Social media use } \rightarrow \text { Customer relationship performance } \\
(\text { Hypothesis } 6+)\end{array}$ & -.0811 & -0.7048 & .4811 \\
\hline
\end{tabular}


Intensive technology use has a positive effect on attitude towards social media $(\beta=.49)$ and on social media use $(\beta=.19)$. Therefore, the more salespeople perceive that they use technology more intensively than their competitors, the more positive their attitude towards social media is, and the more social media they typically use (Hypothesis 1 and Hypothesis 2 accepted). Furthermore, intensive technology use affects social media use not only directly, but also indirectly $(\beta=.18)$, and this effect is also significant (t value $=3.84$; $p$ value $=.000$ ), and so the total effect is altogether $\beta$ $=.37$. This means that an intensive technological environment affects the use of such specific applications as, for example, social media. Intensive technology use affects customer relationships positively $(\beta=.40)$, thus the appropriate technological background is required for effective customer retention (Hypothesis 3 accepted).

With respect to the preliminary expectations, attitude towards social media affects social media use $(\beta=.36)$, thus hypothesis 4 is accepted. This is a surprising result considering the expectation that neither attitude towards social media, nor social media use affects customer relationship performance (Hypothesis 5 and Hypothesis 6 rejected).

\section{CONCLUSIONS AND MANAGERIAL IMPLICATIONS}

Certain technology systems applied in sales (e.g. CRM, SFA, social media) can improve communications and, at the same time, can signify many unexpected burdens for salespeople (Jones et al., 2005). While social media use has been integrated into already existing systems (e.g. social (RM), it is important to enhance its sales focus. In many cases, content is provided by marketing and the messages can be quite general, including branding and PR arguments (see, e.g. Swani, Milne, Brown, Assaf \& Donthu, 2017). It is believed that sales managers must have an active role in the creation of social media content, which has sales relevance, as well. There is a caveat, however: sales managers have to be aware that hard-selling arguments do not work well in social media (see, e.g. Itani et al., 2017). Managers responsible for managing social media activities have to be further aware of the diversity of social media outlets that can be industry- (B2B vs. B2C), or function-specific (e.g. branding vs. sales). As reported by Siamagka, Christodoulides, Michaelidou and Valvi (2015: 93), there is a stronger pref-

FIGURE 2: Structural model and results

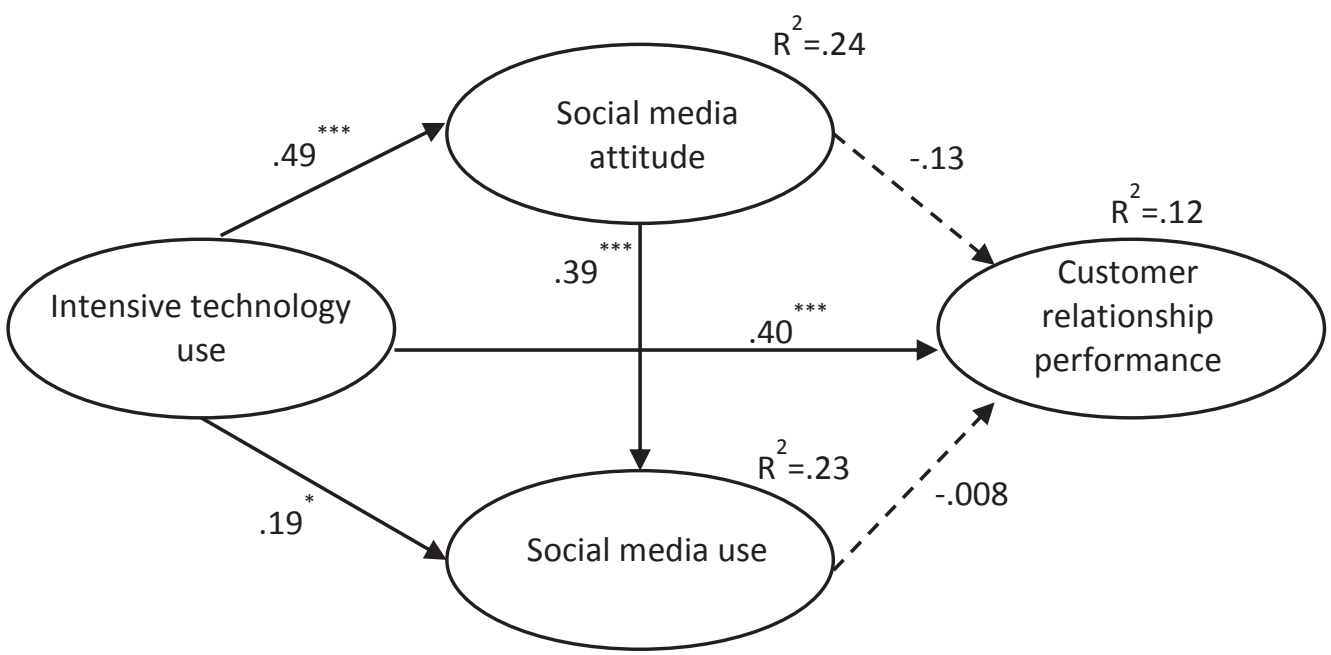

Note: Every path coefficient is standardized $\left({ }^{* * *} p<0.000 ;{ }^{*} p<0.05\right)$. The dotted line represents the falsified hypotheses. Source: authors' own elaboration 
erence in B2B markets for social media outlets that serve as linking mechanisms (e.g. Twitter or Linkedln) than for bonding (such as Facebook). Based on the sample of the present study, it can be concluded that social selling is rather common on Facebook, where understanding and reaching the customer can also be relevant, but the latter steps of the sales process, such as customer need exploration, value proposition, or the closure of the purchase, are normally applied on Facebook. Linkedln is only limitedly present in the whole process, and all the other social media tools are only sporadically understood in the scope of this research.

A second conclusion is that salespeople may consider social media to be curbing their relationship-building competences, mainly based on empathy. This can affect salespeople's work ethic negatively if technology acceptance does not happen in the right manner (Speier \& Venkatesh, 2002). Moreover, if the application of technology has indirect advantages, such as employee motivation, more efficient communication among organizational departments, or the improvement of company image, then the classical tools for salespeople's performance measures do not make visible the real value of technologies (Avlonitis \& Panagopoulos, 2005). Sales managers could alleviate this contradiction by inclusion of the right technology-oriented output measures in sales performance evaluation systems.

Geiger and Turley (2006), based on Speier and Venkatesh (2002), departed from the recognition that technology in personal selling can have miscellaneous effects that can be supportive and hindering at the same time. Although the analysis referred to earlier forms of technology (CRM systems), these were especially interesting in certain sales situations, when relational selling was typical, i.e. longterm cooperation between buyer and seller. Based on this consideration, with the application of technology, different positive and negative effects concerning the relationship competences of salespeople can be observed (Gei- ger \& Turley, 2006: 83433): knowledge of technology represents expertise from the point of view of buyers and gives real added value in many cases; however, it constitutes a limitation in terms of attention paid to the buyer because technology is impersonal at the same time. During communication, additional information that the salesperson can provide via technology can be associated with the risk that the personal knowledge of the salesperson is incomplete, because the salesperson is not forced to memorize more data than is available from the database. The amount of personal information available about the customer is on the one hand an advantage but, on the other hand, it can be a disadvantage because it raises many concerns about privacy.

In sum, technology has many risks besides the opportunity that, if applied and adapted properly, it can contribute positively to salespeople's performance. The results of Geiger and Turley (2006) were somewhat similar to the earlier-mentioned results of Speier and Venkatesh (2002), where the application of technology correlated to salespeople's perceived loss of competency and to the relative freedom and the creative way of filling the gap between buyer and seller (salespeople were proud of these creative ways in these studies). Our findings reveal that even though the use of technology and social media - since it has been available - has become more widespread than a decade ago, some of the reservations of salespeople may still be around. Again, it is proposed that sales managers take a more active role in social media content creation and the social media outlet selection process.

Although the scales functioned properly, $R^{2}$ at customer retention is quite low, which can be explained through several reasons. One reason is that customer relationship performance (customer retention) can be affected by several other factors, as well. Moreover, intensive technology and social media use can guarantee customer retention only to a limited extent. This conclusion questions the myth that social me- 
dia have a more important role than personal relationships built by salespeople.

This study has several further limitations. Some of the most important are the size and structure of the sample 4 and the fact that the constructs were based on salespeople's perceptions. Consequently, because salesperson impressions dominated our study, it is advisable that the situation be analyzed from the aspect of three players. First, the salesperson's opinion can be presented in the future as an individual perspective. Second, a holistic aspect is needed to examine sales organizations' interests from an organizational perspective. Third, the customer's perspective is needed to get a more comprehensive picture of technology and social media phenomena in personal selling. In the future, further research should be done in order to explore the connection between social media applied for business purposes and customer relationship performance. To do this, the sample subjects could be asked in the form of qualitative in-depth interviews about their technology and social media use, in connection with customer retention.

\section{ACKNOWLEDGMENTS}

This publication was prepared within the Széchenyi 2020 program framework (EFOP-3.6.116-2016-00013) under the European Union project "Institutional developments for intelligent specialization at the Székesfehérvár Campus of Corvinus University of Budapest".

\section{References}

1. Ahearne, M., Jones, E., Rapp, A., \& Mathieu, J. (2008). High touch through high tech: The impact of salesperson technology usage on sales performance via mediating mechanisms. Management Science, 54(4), 671-685.

2. Agnihotri, R., Kothandaraman, P., Kashyap, R., \& Singh, R. (2012). Bringing "social" into sales: The impact of salespeople's social media use on service behaviors and value creation. Journal of Personal Selling \& Sales Management, 32(3), 333-348.

3. Andzulis, J. M., Panagopoulos, N. G., \& Rapp, A. (2012). A review of social media and implications for the sales process. Journal of Personal Selling \& Sales Management, 32(3), 305-316.

4. Avlonitis, G. J., \& Panagopoulos, N. G. (2005). Antecedents and consequences of CRM technology acceptance in the sales force. Industrial Marketing Management, 34(4), 355-368.

5. Christ, P., \& Anderson, R. (2011). The impact of technology on evolving roles of salespeople. Journal of Historical Research in Marketing, 3(2), 173-193.

6. Demand Gen Report (2014). B2B buyer behavior survey. Available at: http://www.demandgenreport.com/industry-resources/research/2508-the-2014-b2b-buyer-behavior-survey

7. Dijkstra, T. K., \& Henseler, J. (2015). Consistent partial least squares path modeling. MIS Quarterly, 39(2), 297-316.

8. Durukan, T., \& Bozaci, I. (2012). A survey on determinants of word of mouth in social media. International Journal of Economics and Management Sciences, 1(7), 36-44.

9. Forrester (2017). Social selling: A new B2B imperative. Embrace a programmatic social selling approach to boost sales effectiveness. Available at: https://hootsuite.com/resources/social-selling-b2b-imperative\#

10. Gatignon, H., \& Robertson, T. (1989). Technology diffusion: An empirical test of competitive effects. Journal of Marketing, 53(1), 35-49.

11. Geiger, S., \& Turley, D. (2006). The perceived impact of information technology on salespeople's relational competencies. Journal of Marketing Management, 22(7/8), 827-851.

12. Guesalaga, R. (2016). The use of social media in sales: Individual and organizational antecedents, and the role of customer engagement in social media. Industrial Marketing Management, 54(3), 71-79. 
13. Hair, J. F., Sarstedt, M., Ringle, C. M., \& Mena, J. A. (2012). An assessment of the use of partial least squares structural equation modeling in marketing research. Journal of the Academy of Marketing Science, 40(3), 414-433.

14. Henseler, J., Hubona, G., \& Ray, P. A. (2016). Using PLS path modeling in new technology research: updated guidelines. Industrial Management \& Data Systems, 116(1), 2-20.

15. Honeycutt, E. D., Thelen, T., Thelen, S. T., \& Hodge, S. K. (2005). Impediments to sales force automation. Industrial Marketing Management, 34(4), 313-322.

16. Hu, L., \& Bentler, P. M. (1999). Cutoff criteria for fit indexes in covariance structure analysis: Conventional criteria versus new alternatives. Structural Equation Modeling: A Multidisciplinary Journal, 6(1), 1-55.

17. Itani, O. S., Agnihotri, R., \& Dingus, R. (2017). Social media use in B2B sales and its impact on competitive intelligence collection and adaptive selling: Examining the role of learning orientation as an enabler. Industrial Marketing Management, 66, 64-79.

18. Jones, E., Brown, S. P., Zoltners, A. A., \& Weitz, B. A. (2005). The changing environment of selling and sales management. Journal of Personal Selling \& Sales Management, 25(2), 105-111.

19. Levin, M. A., Hansen, J. M., \& Laverie, D. A. (2012). Toward understanding new sales employees' participation in marketing-related technology: Motivation, voluntariness, and past performance. Journal of Personal Selling \& Sales Management, 32(3), 379-393.

20. Marshall, G. W., Moncrief, W. C., Rudd, J. M., \& Lee, N. (2012). Revolution in sales: The impact of social media and related technology on the selling environment. Journal of Personal Selling \& Sales Management, 32(3), 349-363.

21. Moutot, J. M., \& Bascoul, G. (2008). Effects of sales force automation use on sales force activities and customer relationship management processes. Journal of Personal Selling \& Sales Management, 28(2), 167-184.

22. Podsakoff, P. M., \& Organ, D. W. (1986). Self-reports in organizational research: Problems and prospects. Journal of management, 12(4), 531-544.

23. Rapp, A., Ahearne, M., Mathieu, J., \& Rapp, T. (2010). Managing sales teams in a virtual environment. International Journal of Research in Marketing, 27(3), 213-224.

24. Rapp, A., Trainor, K. J., \& Agnihotri, R. (2010). Performance implications of customer-linking capabilities: Examining the complementary role of customer orientation and CRM technology. Journal of Business Research, 63(11), 1229-1236.

25. Rodriguez, M., Peterson, R. M., \& Krishnan, V. (2012). Social media's influence on business-to-business sales performance. Journal of Personal Selling \& Sales Management, 32(3), 365-378.

26. Rust, R. T., Moorman, C., \& Dickson, P. R. (2002). Getting return on quality: Revenue expansion, cost reduction, or both?. Journal of Marketing, 66(4), 7-24.

27. Schillewaert, N., Ahearne, M. J., Frambach, R. T., \& Moenaert, R. K. (2005). The adoption of information technology in the sales force. Industrial Marketing Management, 34(4), 323-336.

28. Schultz, R. J., Schwepker Jr., C. H., \& Good, D. J. (2012). Social media usage: an investigation of B2B salespeople. American Journal of Business, 27(2), 174-194.

29. Siamagka, N. T., Christodoulides, G., Michaelidou, N., \& Valvi, A. (2015). Determinants of social media adoption by B2B organizations. Industrial Marketing Management, 51, 89-99.

30. Speier, C., \& Venkatesh, V. (2002). The hidden minefields in the adoption of sales force automation technologies. Journal of Marketing, 66(3), 98-111.

31. Swani, K., Milne, G. R., Brown, B. P., Assaf, A. G., \& Donthu, N. (2017). What messages to post? Evaluating the popularity of social media communications in business versus consumer markets. Industrial Marketing Management, 62, 77-87. 
32. Trainor, K. J. (2012). Relating social media technologies to performance: A capabilities-based perspective. Journal of Personal Selling \& Sales Management, 32(3), 317-331.

33. Trainor, J. K., Andzulis, J., Rapp, A., \& Agnihotri, R. (2014). Social media technology usage and customer relationship performance: A capabilities-based examination of social CRM. Journal of Business Research, 67(6), 1201-1208.

34. Weinstein, L., \& Mullins, R. (2012). Technology usage and sales teams: a multilevel analysis of the antecedents of usage. Journal of Personal Selling \& Sales Management, 32(2), 245-259.

35. Weitz, B. A., \& Bradford, K. D. (1999). Personal selling and sales management: A relationship marketing perspective. Journal of the Academy of Marketing Science, 27(2), 241-254.

\section{Appendix: Measurement and reliability of constructs}

\begin{tabular}{|c|c|c|c|c|}
\hline $\begin{array}{c}\text { Construct } \\
\text { (Dijkstra- } \\
\text { Henseler's } \rho_{A} \text { ) }\end{array}$ & Item & $\begin{array}{l}\text { Factor } \\
\text { loading }\end{array}$ & Mean & $\begin{array}{c}\text { Standard } \\
\text { deviation } \\
\text { (SD) }\end{array}$ \\
\hline \multirow{4}{*}{$\begin{array}{l}\text { Intensive } \\
\text { technology use } \\
\left(\rho_{A}=.891\right)\end{array}$} & $\begin{array}{l}\text { Compared to our competitors' sales reps, we use } \\
\text { information technology extensively. }\end{array}$ & .873 & 4.76 & 1.68 \\
\hline & $\begin{array}{l}\text { Compared to our competitors' sales forces, we are } \\
\text { equipped with up-to-date information technology. }\end{array}$ & .840 & 4.80 & 1.64 \\
\hline & $\begin{array}{l}\text { Compared to the competing sales executives, our sales } \\
\text { executives use a lot of sales technology. }\end{array}$ & .880 & 4.72 & 1.51 \\
\hline & $\begin{array}{l}\text { Compared to our competitors' salespeople, we rely on } \\
\text { information technology in dealing with customers. }\end{array}$ & .822 & 4.59 & 1.59 \\
\hline \multirow{4}{*}{$\begin{array}{l}\text { Social media } \\
\text { attitude } \\
\left(\rho_{A}=.923\right)\end{array}$} & Social media are a good way to communicate with partners. & .913 & 4.15 & 2.04 \\
\hline & Social media tools make communication easy. & .891 & 4.78 & 1.98 \\
\hline & Social media are good tools for getting new relationships. & .898 & 4.76 & 2.01 \\
\hline & Social media tools make selling easier. & .886 & 4.30 & 1.86 \\
\hline \multirow{5}{*}{$\begin{array}{l}\text { Social media } \\
\text { use } \\
\left(\rho_{A}=.891\right)\end{array}$} & I ask for advice from partners. & .815 & 2.65 & 1.81 \\
\hline & I collect references from partners. & .847 & 3.17 & 1.95 \\
\hline & I get information from potential and actual partners. & .765 & 4.51 & 1.98 \\
\hline & I contact potential partners. & .846 & 3.65 & 2.05 \\
\hline & I contact opinion leaders. & .853 & 2.90 & 1.89 \\
\hline \multirow{5}{*}{$\begin{array}{l}\text { Customer } \\
\text { relationship } \\
\text { performance } \\
\left(\rho_{\mathrm{A}}=.929\right)\end{array}$} & Our customers have worked with our firm for a long time. & .931 & 6.02 & 0.95 \\
\hline & Once we get new customers, they tend to stay with our firm. & .932 & 5.96 & 0.95 \\
\hline & Our customers are very loyal to our firm. & .847 & 5.93 & 0.94 \\
\hline & Our customers are satisfied with our company. & 655 & 5.90 & 1.08 \\
\hline & Customer retention is very important to our firm. & .667 & 6.63 & 0.85 \\
\hline
\end{tabular}

Note: All items were measured on a seven-point Likert scale ranging from 1 (strongly disagree) to 7 (strongly agree).

\section{Endnotes}

CRM and SFA: CRM is a business strategy that contains processes and technology that improve customer relationships. SFA primarily refers to the technological tools related to this complex system (Avlonitis \& Panagopoulos, 2005, p. 355).

2 Lead: Leads are prospective customers who show an interest in a given product.

3 In that 2006 research, the respondents of the qualitative study were salespeople with considerable experience, who were typically not technophobic (i.e. they did not have any aversion to technology).

4 Because of the small size of the sample, there were no significant differences among the different geographical regions concerning the measured constructs and their connections. 